\title{
DISCUSSION
}

\section{Reinforcement bond capacity}

\author{
R. A. JEWELL (1990). Géotechnique 40, No. 3, 513-518
}

\section{E. M. Palmeira, University of Brasilia, and}

G. W. E. Milligan, University of Oxford

The Author has presented some developments of the method of determining bond capacity of grid reinforcement, originally introduced by Jewell, Milligan, Sarsby \& Dubois (1984). He has made use of experimental data published by Palmeira \& Milligan (1989), but is critical of the introduction of an empirical relationship to correlate this data. We accept the usefulness of the Author's approach, particularly for practical design purposes, but would like to make the following comments.

The increase in bearing stress when the diameter of the grid bearing member is relatively small in relation to the soil mean particle diameter, shown in Fig. 3, should be treated with caution. These results were all obtained using dense uniform Leighton Buzzard sand, and would not necessarily apply with well-graded fills or soils with significantly more or less angular particles.

The results from tests with a small number $n$ of bearing members, shown in Fig. 5, could equally well be plotted in Fig. 4; the special status of the first bearing member can be taken into account as suggested by the Author, despite possible interference from members behind it or influence from the box boundaries in pull-out tests. When that is done, points which lie below the predicted lines in Fig. 5 plot above the predicted relations in Fig. 4, and vice versa. It can be seen that for $S / \alpha_{\mathrm{b}} B<\left(S / \alpha_{\mathrm{b}} B\right)_{\phi}$, the apparent bond coefficient is equal to or greater than unity for tests with small values of $n$, but less than unity for large values of $n$. This suggests that the interaction mechanism for closely spaced bearing members is more complex than envisaged by the Author's approach, and is not independent of $n$ when the number of bearing membcrs involved is small. In such cases the empirical relation of Palmeira \& Milligan (1989) may be useful, at least for checking data from pull-out tests with small numbers of bearing members. However, given the inevitable differences between pull-out tests and field situations, the use of bond coefficients greater than unity for design purposes is not recommended, even if only a few bearing members are involved.

The most important factor for design is the

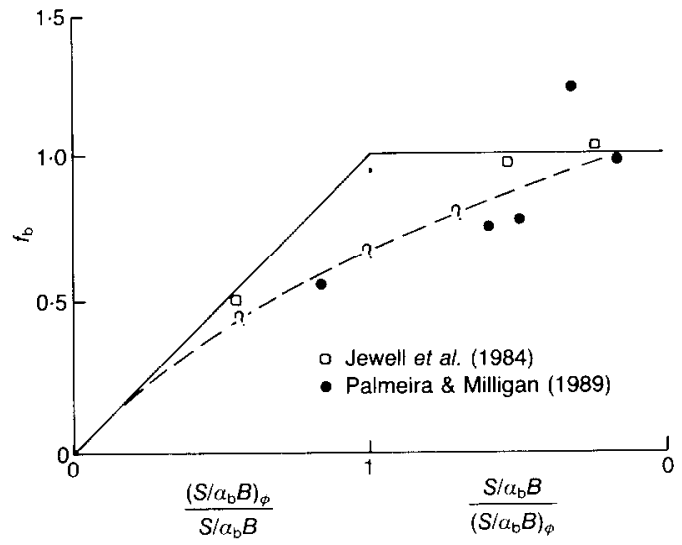

Fig. 8 Comparison between observed and predicted values of $f_{\mathrm{b}}$

amount by which the actual bond coefficient is smaller than that predicted; this is shown as a rounding-off between the two straight-line relations in Fig. 4. However, most of the experimental data shown on this plot (from Jewell et al., 1984), although the best available at the time, are difficult to interpret with great confidence. The more recent high-quality data for tests with larger values of $n$ from Palmeira \& Milligan (1989) are plotted in this form in Fig. 8, and suggest that the rounding-off may be more severe than was previously suggested. However, much more information is needed, from many different types of soil and grid, before a lower-bound envelope for the bond capacity of grids can be properly established. Meanwhile, reasonably conservative selection of the friction angle for the soil will ensure that the design value will not exceed the bond available in the field.

\section{REFERENCES}

Jewell, R.A., Milligan, G.W.E., Sarsby, R.W. \& Dubois, D. (1984). Interaction between soil and grids. Polymer grid reinforcement, pp. 18-30. London: Thomas Telford.

Palmeira, E.M. \& Milligan, G.W.E. (1989). Scale and other factors affecting the results of pull-out tests of grids buried in sand. Géotechnique 39, No. 3, 511524. 


\title{
Initial investigation of the soft clay test site at Bothkennar
}

\author{
D. F. T. NASH, J. J. M. POWELL and I. M. LLOYD (1992). Géotechnique 42, No. 2, 163-181
}

\section{G. Mesri, University of Illinois at Urbana- Champaign}

The most distinctive feature of Bothkennar clay is its ratios of undrained shear strength to preconsolidation pressure. For example, at the average value of plasticity index of $40 \%$, the $s_{\mathrm{u}}(\mathrm{FV}) / \sigma_{\mathrm{p}}{ }^{\prime}$ of Bothkennar clay is $0 \cdot 32$, obtained from Fig. 13 together with $\sigma_{\mathrm{p}}{ }^{\prime} / \sigma_{\mathrm{vo}}{ }^{\prime}=1.55$. In contrast, a value of $0 \cdot 26$ pertains to inorganic soft clays, from the Bjerrum-Mesri relationship (Mesri, 1975). This distinctive behaviour, which I believe is rclatcd to the organic content, has significant implications with respect to the undrained shear strength $s_{\mathrm{u}}(\mathrm{mob})$ mobilized in full-scale field situations. Bothkennar clay has a $3-8 \%$ organic content, in the form of marine organisms which have attached themselves to mineral particles (Paul, Peacock \& Wood, 1992).

The distinctive undrained strength behaviour of organic clays was appreciated by La Rochelle (1979) and investigated by La Rochelle, Tavenas, Leroueil \& Roy (1980) who found that

$$
s_{\mathbf{u}}(\mathrm{mob})=0.22 \sigma_{\mathrm{p}}{ }^{\prime}
$$

which is based on an interpretation of Bjerrum's data made by Mesri (1975), provided a good indication of instability in inorganic clays, but did not seem to be applicable to soft organic cohesive soils. A similar conclusion was reached by Larsson (1980) who stated that there are no empirical correlations for normalized undrained shear strength in organic Scandinavian clays at present.'

Based on the back-analyses of instabilities in organic cohesive soils carried out by Trak et al. (1980), as well as the values of $s_{\mathrm{v}}(\mathrm{FV}) / \sigma_{\mathrm{p}}{ }^{\prime}$ for organic clays, for mobilized undrained strength of organic clays I recommend the equation

$$
s_{\mathrm{u}}(\mathrm{mob})=0.26 \sigma_{\mathrm{p}}{ }^{\prime}
$$

The application of the Bjerrum field vane correction factor of 0.85 at $I_{\mathrm{p}}=40 \%$ (Bjerrum, 1973) to the $s_{\mathrm{u}}(\mathrm{FV}) / \sigma_{\mathrm{p}}{ }^{\prime}=0.32$ of Bothkennar clay leads to $s_{\mathrm{u}}(\mathrm{mob})=0.27 \sigma_{\mathrm{p}}^{\prime}$. Mesri (1989) showed that equation (6) is also obtained from laboratory undrained shear tests by taking into account mode of shear and time to failure effects. The mobilized field strength was computed from the laboratory tests using the equation

$$
\begin{aligned}
& s_{\mathrm{u}}(\mathrm{mob})= \\
& \frac{1}{3}\left[\frac{s_{\mathrm{u}}\left(K_{\mathrm{o}} T C\right)}{\sigma_{\mathrm{p}}{ }^{\prime}}+\frac{s_{\mathrm{u}}(D S S)}{\sigma_{\mathrm{p}}{ }^{\prime}}+\frac{s_{\mathrm{u}}\left(K_{\mathrm{o}} T E\right)}{\sigma_{\mathrm{p}}^{\prime}}\right] \mu_{\mathrm{RL}}
\end{aligned}
$$

where $\mu_{\mathrm{RL}}$ corrects for the difference in time to failure between laboratory shear tests and field instabilities. The values of $s_{\mathrm{u}}\left(K_{0} T C\right) / \sigma_{\mathrm{p}}{ }^{\prime}=0.38$, $s_{\mathrm{u}}(D S S) / \sigma_{\mathrm{p}}{ }^{\prime}=0.31$ and $s_{\mathrm{u}}\left(K_{0} / T E\right) / \sigma_{\mathrm{p}}{ }^{\prime}=0.19$ for Bothkennar clay, together with $\mu_{\mathrm{RL}}=0.894$ at $I_{\mathrm{p}}=40 \%$, lead to $s_{\mathrm{u}}(\mathrm{mob})=0 \cdot 26 \sigma_{\mathrm{p}}^{\prime}$. These data correspond to undrained shear tests on Sherbrooke samples and ocdometer tests on Sherbrooke and Laval samples (Hight, Böese, Butcher, Clayton \& Smith, 1992; Hight, Bond \& Legge, 1992). Thus, both field vane and laboratory undrained shear tests on Bothkennar clay lead to a mobilized undrained shear strength consistent with equation (7).

When the question first arose (La Rochelle, $1979)$, only data on $s_{\mathrm{u}}(F V)$ and $\sigma_{\mathrm{p}}{ }^{\prime}$ were available for organic cohesive soils. I believed that the unusually high values of $s_{\mathrm{u}}(F V) / \sigma_{\mathrm{p}}{ }^{\prime}$ were related to the measurement of $s_{\mathrm{u}}(F V)$ and $\sigma_{\mathrm{p}}{ }^{\prime}$. It was speculated that local drainage, aided by organic inclusions and interference of organic fibres with the vane blades, contributed to an overestimate of $s_{\mathrm{u}}(F V)$, and that the same factors increased sample disturbance and led to an underestimate of $\sigma_{\mathrm{p}}^{\prime}$ from the oedometer test. In the light of in situ as well as laboratory undrained shear strength data on Bothkennar clay, these explanations must be revised. For the Bothkennar clay, not only $s_{\mathrm{u}}(F V) / \sigma_{\mathrm{p}}{ }^{\prime}$, but also $s_{\mathrm{u}}\left(K_{0} T E\right) / \sigma_{\mathrm{p}}{ }^{\prime}$ and $s_{\mathrm{u}}(D S S) / \sigma_{\mathrm{p}}{ }^{\prime}$ are higher than those for inorganic clays. The molecular organic residues that connect soil particles apparently provide resistance against relative particle movement, with a maximum effect in undrained shear, but make a smaller contribution in drained oedometer loading. Undrained shear behaviour of Bothkennar clay cannot be explained by bedding and lamination with coarse angular silt particles, as the unusual behaviour described here is most pronounced in the organic mottled facies. 
Subsurface conditions at the Bothkennar soft clay test site have been well defined by means of in situ and laboratory tests. A further step would be a full-scale test embankment loading to failure to evaluate $s_{\mathrm{u}}$ (mob) for Bothkennar clay. In the meantime it is suggested that values of $s_{\mathrm{u}}(\mathrm{mob})$ according to equation (7), together with the end of primary $\sigma_{p}^{\prime}$ from oedometer tests on Laval or Sherbrooke quality samples, may be used for undrained stability analyses of embankments on Bothkennar clay.

\section{REFERENCES}

Bjerrum, L. (1973). Problems of soil mechanics and construction on soft clays. Proc. 8th Int. Conf. Soil Mech., Moscow, 3, 111-159.

Hight, D. W., Böese, R., Butcher, A. P., Clayton, C. R. I. \& Smith, P. R. (1992). Disturbance of the Bothkennar clay prior to laboratory testing. Géotechnique 42, No. 2, 199-217.
Hight, D. W., Bond, A. J. \& Legge, J. D. (1992). Characterization of the Bothkennar clay: an overview. Géotechnique 42, No. 2, 303-347.

La Rochelle, P. (1979). Personal communication.

Larsson, R. (1980). Undrained shear strength in stability calculation of embankments and foundations on soft clay. Can. Geotech. J., 17, 591-602.

Mesri, G. (1975). Discussion of new design procedure for stability of soft clays. Proc. Am. Soc. Civ. Engrs 101, GT4, 409-412.

Mesri, G. (1989). A re-evaluation of $s_{\mathrm{u}}(\mathrm{mob})=0.22 \sigma_{\mathrm{p}}{ }^{\prime}$ using laboratory shear tests. Can. Geotech. J. 26, No. 1, 162-164.

Paul, M. A., Peacock, J. D. \& Wood, B. F. (1992). The engineering geology of the coarse clay at the National Soft Clay Research Site, Bothkennar. Géotechnique 42, No. 2, 183-198.

Trak, B., La Rochelle, P., Tavenas, F., Leroueil, S. \& Roy, M. (1980). A new approach to the stability analysis of embankments on sensitive clays. Can. Geotech. J. 17, 526-544. 